\title{
Genetic comparison of Macoma balthica (Bivalvia, Telinidae) from the eastern and western North Atlantic Ocean
}

\author{
Brian W. Meehan* \\ Virginia Institute of Marine Science, School of Marine Science, College of William and Mary, Gloucester Point, \\ Virginia 23062, USA
}

\begin{abstract}
The telinid bivalve Macoma balthica is common to both marine and estuarine soft-bottom habitats of the northern hemisphere. To determine if populations in the eastern and western North Atlantic Ocean are conspecific, the genetic composition of these populations was examined. Differences in genetic composition, as determined by enzyme electrophoresis, were observed between populations from the eastern and western North Atlantic. One locus was unique to western North Atlantic populations and 3 others differed in allele composition and frequencies. Allopatric populations of $M$. balthica from the eastern and western North Atlantic can be considered as separate and sibling species.
\end{abstract}

\section{INTRODUCTION}

The tellinid bivalve Macoma balthica is common to both marine and estuarine soft-bottom habitats of the northern hemisphere (McErlean 1967, Castagna \& Chanley 1973, Green 1973, Abbott 1974, Chambers \& Milne 1975, McLusky \& Allen 1976, Ankar 1977. Beukema et al. 1978, Lubinsky 1980). In the western North Atlantic Ocean, this species occurs in coastal waters of western Greenland and the lower Canadian Arctic south to North Carolina. In the eastern North Atlantic it occurs from the Bay of Biscay, France, to northern Scandinavia and the White Sea. Such a vast geographic range is not unique among the marine fauna; however, differences in life history strategies, morphology and habitat type (Gilman 1977, Elliot 1979, Meehan 1984) among geographically disjunct populations may indicate that geographically widespread populations are genetically unique.

A limited portion of the genome of a population can be determined by the examination of enzymes using electrophoretic techniques (Brewer 1970. Avise 1975, Markert 1975). The genetic population structure of many organisms has been determined using this

\footnotetext{
- Virginia Institute of Marine Science Contribution No. 1217
}

(c) Inter-Research/Printed in F. R. Germany technique (see reviews by Ayala 1975, Gooch 1975 , Nevo 1978, Burton 1983). Reid \& Dunnil (1969) have utilized gastric and digestive enzymes to distinguish 8 Pacific east-coast species of Macoma, not including $M$ balthica. Green et al. (1983) used enzymes to investigate the relation between some life-history characteristics and genetic population structure of an intertidal population of $M$. balthica. If $M$. balthica populations on the eastern and western North Atlantic are represented by distinct gene pools, this may be manifested as differences in electrophoretically detectable enzyme variations.

\section{Materials and Methods}

Specimens of Macoma balthica were sampled from sites on both the east and west coasts of the North Atlantic Ocean (Table 1). Live specimens were transferred to the Virginia Institute of Marine Science (USA) or the Netherlands Institute for Sea Research (The Netherlands) where they were maintained in aquaria with flowing seawater under ambient conditions.

Enzyme variation was examined using horizontal starch gel electrophoresis (Brewer 1970). Samples were prepared for electrophoresis; electrophoretic conditions and detection were described in detail by 
Table 1. Macoma balthica. Geographic location and source of studied populations

\begin{tabular}{|c|c|c|}
\hline $\begin{array}{l}\text { Population } \\
\text { number }\end{array}$ & Location & Source \\
\hline 1 & Sarah's Creek, York River Virginia, USA & $\begin{array}{l}\text { Mr. Brian Meehan, Virginia } \\
\text { Inst. of Marine Science, Gloucester Point, Virginia }\end{array}$ \\
\hline 2 & Shark River, New Jersey, USA & $\begin{array}{l}\text { Ms. Joy Goodsill, Rutgers Univ. } \\
\text { Rutgers Shellfish Lab. Port Norris, New Jersey, USA }\end{array}$ \\
\hline 3 & Newark Bay, New Jersey, USA & $\begin{array}{l}\text { Dr. Mike McCormick, Montclair } \\
\text { State College, Upper Montclair, New Jersey, USA }\end{array}$ \\
\hline 4 & $\begin{array}{l}\text { Barn Island Salt Marsh, Barn Island State } \\
\text { Park, Connecticut, USA }\end{array}$ & $\begin{array}{l}\text { Dr. Bob Whiltlach, } \\
\text { Univ. of Connecticut, Groton, Connecticut, USA }\end{array}$ \\
\hline 5 & $\begin{array}{l}\text { Jackson Marine Lab. New Hampshire, } \\
\text { USA }\end{array}$ & $\begin{array}{l}\text { Dr. Larry Harris, } \\
\text { Univ. of New Hampshire, Durham, New Hampshire, USA }\end{array}$ \\
\hline 6 & $\begin{array}{l}\text { Pottery Creek, Passamaquoddy Bay, } \\
\text { New Brunswick, Canada }\end{array}$ & $\begin{array}{l}\text { Ms. Leslie Linkletter, Biol. Station, } \\
\text { St. Andrews, New Brunswick, Canada }\end{array}$ \\
\hline 7 & Churchill, Hudson Bay, Canada & $\begin{array}{l}\text { Dr. Roger H. Green, Univ. of Western Ontario, } \\
\text { Ontario, Canada }\end{array}$ \\
\hline 8 & Disko Fjord, Greenland & $\begin{array}{l}\text { Dr. G. Hopner Petersen, } \\
\text { Zooligisk Museum Kobenhavn, Denmark }\end{array}$ \\
\hline 9 & St. Malo Bay, St. Malo, France & $\begin{array}{l}\text { Mr. Franciose Lang, } \\
\text { Lab. Maritime, Dinard, France }\end{array}$ \\
\hline 10 & $\begin{array}{l}\text { The Wadden Sea, Den Helder, } \\
\text { The Netherlands }\end{array}$ & $\begin{array}{l}\text { Dr. Jan J. Beukema, The Netherlands Institute } \\
\text { for Sea Research, Texel, The Netherlands }\end{array}$ \\
\hline 11 & Niva Bay, Øresund, Denmark & $\begin{array}{l}\text { Mr. Paul B. Madsen, Marine } \\
\text { Pollution Lab., Charlettenlund, Denmark }\end{array}$ \\
\hline 12 & $\begin{array}{l}\text { University of Helsinki, Zoological } \\
\text { Station Tvärminne, Finland }\end{array}$ & $\begin{array}{l}\text { Dr. Sirrka-Lisa Aho-Varvio, } \\
\text { Univ. of Helsinki, Helsinki, Finland }\end{array}$ \\
\hline
\end{tabular}

Meehan (1984). Adductor-muscle tissue and digestive diverticular were homogenized in $0.1 \mathrm{M}$ tris buffer $\mathrm{pH}$ 7.0 with $20 \%$ glycerol and centrifuged at $2000 \mathrm{~g}$ for 20 min. Enzymes examined include malate dehydrogenase, phosphoglucose isomerase, phosphoglucomutase, and an aminopeptidase. Phosphoglucose isomerase and aminopeptidase were electrophoresed on a discontinuous lithium hydroxide buffer $\mathrm{pH} 8.4$ (Selander et al. 1969). Phosphoglucomutase was on a maleic acid electrode buffer containing $0.1 \mathrm{M}$ tris, $0.1 \mathrm{M}$ maleic acid, 0.01M EDTA and $0.01 \mathrm{M} \mathrm{MgCl}_{2}$, and adjusted to pH 7.4 with $\mathrm{NaOH}$, the gel buffer was 1:9 dilution of this. Malate dehydrogenase was on a tris-citrate electrode buffer consisting of $0.135 \mathrm{M}$ Tris and $0.004 \mathrm{M}$ citric acid and adjusted to $\mathrm{pH} 7.3$ with $\mathrm{NaOH}$, the gel buffer was a 1:9 dilution of this. Detection of enzymes was performed following the methods of Shaw \& Prassad (1969); leucyl-1-alanine was used as a substrate for the aminopeptidase enzyme. At each locus, the fastest migrating allele was designated ' $A$ ', slower alleles as 'B', 'C', 'D', etc. Data were analysed using the computer software package Biosys-1 (Swofford \& Selander 1981). For each population, allele frequencies and conformity of genotype frequencies to the Hardy-Weinberg expectations were determined. Comparisons between populations were made using Nei's unbiased genetic identity, cluster analyses (unweighted pair group method), and chi-square tests for homogeneity between populations.

\section{RESULTS}

The allele frequencies at studied loci for the populations examined are given in Table 2. Three enzymes were polymorphic in all populations. A population is considered polymorphic if the frequency of the most common allele does not exceed 0.95. Because of difficulties in resolving the aminopeptidase enzyme, it was not included in the analysis of eastern North Atlantic populations. The allele frequencies of each of the investigated loci are discussed below.

\section{Malate dehydrogenase-1 (MDH-1)}

The MDH-1 locus was unique to populations in the western North Atlantic Ocean. Two common alleles and 1 rare allele occurred at this locus. The rare allele occurred only at the Shark River population (2). 
Table 2. Macoma balthica. Sample sizes (n) and allele frequencies at each locus for each population investigated

\begin{tabular}{|c|c|c|c|c|c|c|c|c|c|c|}
\hline \multirow[b]{2}{*}{ Locus } & \multicolumn{10}{|c|}{ Population } \\
\hline & 1 & 2 & 3 & 4 & 5 & 6 & 9 & 10 & 11 & 12 \\
\hline \multicolumn{11}{|l|}{$\mathrm{MDH}-1$} \\
\hline$(\mathrm{N})$ & 49 & 35 & 50 & 30 & 30 & 40 & 64 & 30 & 60 & 60 \\
\hline$A$ & 0.000 & 0.014 & 0.000 & 0.000 & 0.000 & 0.000 & 0.000 & 0.000 & 0.000 & 0.000 \\
\hline $\mathrm{B}$ & 0.663 & 0.643 & 0.660 & 0.617 & 0.633 & 0.650 & 0.000 & 0.000 & 0.000 & 0.000 \\
\hline C & 0.337 & 0.343 & 0.340 & 0.383 & 0.367 & 0.350 & 0.000 & 0.000 & 0.000 & 0.000 \\
\hline$D$ & 0.000 & 0.000 & 0.000 & 0.000 & 0.000 & 0.000 & 0.000 & 0.000 & 0.000 & 0.000 \\
\hline $\mathrm{E}$ & 0.000 & 0.000 & 0.000 & 0.000 & 0.000 & 0.000 & 0.000 & 0.000 & 0.000 & 0.000 \\
\hline \multicolumn{11}{|l|}{$\mathrm{MDH}-2$} \\
\hline (N) & 50 & 35 & 50 & 30 & 30 & 40 & 64 & 30 & 60 & 60 \\
\hline$A$ & 0.000 & 0.000 & 0.000 & 0.000 & 0.000 & 0.025 & 0.000 & 0.000 & 0.000 & 0.000 \\
\hline B & 1.000 & 1.000 & 1.000 & 1.000 & 1.000 & 0.975 & 0.000 & 0.000 & 0.000 & 0.000 \\
\hline $\mathrm{C}$ & 0.000 & 0.000 & 0.000 & 0.000 & 0.000 & 0.000 & 1.000 & 1.000 & 1.000 & 1.000 \\
\hline \multicolumn{11}{|l|}{ PGI } \\
\hline A & 0.000 & 0.000 & 0.000 & 0.000 & 0.017 & 0.027 & 0.027 & 0.000 & 0.000 & 0.017 \\
\hline B & 0.250 & 0.071 & 0.031 & 0.017 & 0.033 & 0.027 & 0.125 & 0.200 & 0.150 & 0.092 \\
\hline $\mathrm{C}$ & 0.488 & 0.443 & 0.583 & 0.567 & 0.400 & 0.351 & 0.330 & 0.683 & 0.525 & 0.400 \\
\hline$D$ & 0.262 & 0.486 & 0.354 & 0.417 & 0.483 & 0.595 & 0.518 & 0.117 & 0.317 & 0.483 \\
\hline $\mathrm{E}$ & 0.000 & 0.000 & 0.031 & 0.000 & 0.050 & 0.000 & 0.000 & 0.000 & 0.008 & 0.008 \\
\hline $\mathrm{F}$ & 0.000 & 0.000 & 0.000 & 0.000 & 0.017 & 0.000 & 0.000 & 0.000 & 0.000 & 0.000 \\
\hline \multicolumn{11}{|l|}{ PGM } \\
\hline A & 0.000 & 0.000 & 0.000 & 0.000 & 0.000 & 0.000 & 0.032 & 0.000 & 0.068 & 0.042 \\
\hline $\mathrm{B}$ & 0.000 & 0.000 & 0.000 & 0.000 & 0.000 & 0.000 & 0.429 & 0.200 & 0.534 & 0.358 \\
\hline $\mathrm{C}$ & 0.000 & 0.000 & 0.000 & 0.000 & 0.000 & 0.000 & 0.349 & 0.483 & 0.280 & 0.367 \\
\hline$D$ & 0.080 & 0.200 & 0.167 & 0.054 & 0.017 & 0.045 & 0.151 & 0.283 & 0.093 & 0.150 \\
\hline $\mathrm{E}$ & 0.273 & 0.414 & 0.667 & 0.321 & 0.467 & 0.439 & 0.032 & 0.033 & 0.017 & 0.075 \\
\hline $\mathrm{F}$ & 0.443 & 0.371 & 0.125 & 0.554 & 0.333 & 0.500 & 0.008 & 0.000 & 0.008 & 0.008 \\
\hline $\mathrm{G}$ & 0.205 & 0.014 & 0.042 & 0.071 & 0.167 & 0.015 & 0.000 & 0.000 & 0.000 & 0.000 \\
\hline $\mathrm{H}$ & 0.000 & 0.000 & 0.000 & 0.000 & 0.017 & 0.000 & 0.000 & 0.000 & 0.000 & 0.000 \\
\hline \multicolumn{11}{|l|}{ APP-2 } \\
\hline$(\mathrm{N})$ & 47 & 31 & 46 & 28 & 29 & 24 & & & & \\
\hline A & 0.170 & 0.339 & 0.315 & 0.250 & 0.397 & 0.396 & & & & \\
\hline B & 0.340 & 0.403 & 0.413 & 0.232 & 0.397 & 0.313 & & & & \\
\hline C & 0.489 & 0.258 & 0.272 & 0.518 & 0.207 & 0.292 & & & & \\
\hline
\end{tabular}

\section{Malate dehydrogenase-2 (MDH-2)}

MDH-2 was monomorphic in all populations except the Pottery Creek population (6), which contained 1 fast migrating, relatively rare allele. The western North Atlantic populations are represented by allele 'B', the eastern North Atlantic populations by allele 'C'.

\section{Phosphoglucose isomerase (PGI)}

PGI was represented by as many as 6 alleles in 1 population. Allele ' $F$ ' at the New Hampshire population (5) was the only allele unique to the western North Atlantic for this locus. Generally, allele ' $B$ ' was more common in the eastern North Atlantic and allele ' $E$ ' was more common in the western North Atlantic. In the Sarah's Creek population (1) allele 'B' occurs at a much higher frequency (seemingly at the expense of allele 'D') than in other western North Atlantic populations.

\section{Phosphoglucomutase (PGM)}

Of the 8 alleles representing this locus, 3 (' $D$ ', ' $E$ ', ' $F$ ') were shared among nearly all populations studied. Two distinct alleles ('G', ' $\mathrm{H}$ ') occurred in the western North Atlantic populations, and 3 distinct alleles ('A', 'B' ' C') occurred in the eastern North Atlantic populations. Allele ' $F$ ' was common in the western North Atlantic but it occured at very low frequencies in the eastern North Atlantic. Allele ' $\mathrm{H}$ ' occurred only in the 
New Hampshire population at low frequency. Alleles unique to the eastern North Atlantic represent $60 \%$ or more of all alleles present at this locus.

\section{Aminopeptidase (AP)}

Because this locus was scored only for the western North Atlantic populations an amphi-Atlantic comparison was not possible. This locus contained 3 alleles shared among all the western North Atlantic populations studied.

The allele frequencies at each of the populations studied agree with Hardy-Weinberg expectations, except in the Tvärminne (12) and Sarah's Creek (1) populations. The deviation from Hardy-Weinberg equilibrium for the PGI locus in the Tvarminne (12) population could be caused by a combination of sample size and presence of some rare alleles (Table 2). When the rare alleles at the PGI locus of the Tvärminne (12) population are pooled into a single group, the allele frequencies are in strong agreement with HardyWeinberg expectations. The allele frequencies at all of the polymorphic loci for the Sarah's Creek population (1) are in disagreement with Hardy-Weinberg expectations. Also, the MDH-1 and the PGI loci of the Sarah's Creek (1) population showed a strong difficiency of heterozygotes. The Sarah's Creek population is located very near the southern distributional limit of Macoma balthica. Perhaps, the departures from the HardyWeinberg equilibrium and the heterozygote difficiencies are a reflection of this (i.e. marginal habitat). As a marginal habitat, this population may be partially isolated and it may be subject to extraordinary strong selection at these loci.

With regard to all the loci examined, the populations studied on each side of the North Atlantic are very similar to one another (Table 3), but not homogeneous (Table 5). The average genetic identity among western North Atlantic populations is 0.975, among eastern
North Atlantic populations 0.971. In contrast, eastern and western North Atlantic populations are quite different from one another (Fig. 1; Tables 3 and 4). The average genetic identity between eastern and western North Atlantic populations is 0.169 . The most striking difference between eastern and western North Atlantic populations occurs at the MDH loci (Table 2). Along the western North Atlantic this enzyme system is coded for by 2 loci, MDH-1 and MDH-2; on the eastern North Atlantic only the MDH-2 locus is present.

\section{DISCUSSION}

The slight variations in allele frequencies within the populations studied were not unexpected. Variations in allele frequencies along microgeographic and macrogeographic ranges are common in marine bivalves and are often associated with environmental and habitat differences (Koehn \& Mitton 1972, Koehn et al. 1973, Levinton 1972, Mitton et al. 1973, Singh \& Zouros 1978, Theisen 1978, Koehn 1983). Green et al. (1983) found that the genetic heterozygosity of 2 intertidal populations of Macoma balthica increased slightly with increased distance above mean low water. It is likely that the variations in allele frequencies within each of the populations studied are caused by environmental and habitat differences. Unique alleles among eastern or western North Atlantic populations are at such low frequencies that they do not significantly differentiate populations, and it could be that they have simply remained undetected in other populations.

The presence of the MDH-1 locus in the western North Atlantic, as well as many alleles unshared at common loci between eastern and western North Atlantic populations, strongly indicates that the eastern and western North Atlantic populations of Macoma balthica are genetically distinct. As a general descriptor, genetic similarity values indicate that eastern and

Table 3. Macoma balthica. Matrix of Nei's unbiased identity coefficients calculated from allele frequencies using Biosys-1 (Swofford \& Selander 1981)

\begin{tabular}{|c|c|c|c|c|c|c|c|c|c|c|}
\hline Population & 1 & 2 & 3 & 4 & 5 & 6 & 7 & 8 & 9 & 10 \\
\hline 1 & $\cdots$ & 0.974 & 0.937 & 0.985 & 0.974 & 0.956 & 0.143 & 0.177 & 0.158 & 0.156 \\
\hline 2 & & $\cdots \cdots$ & 0.978 & 0.992 & 0.997 & 0.996 & 0.182 & 0.173 & 0.169 & 0.195 \\
\hline 3 & & & $\cdots \cdots$ & 0.946 & 0.977 & 0.945 & 0.165 & 0.194 & 0.172 & 0.188 \\
\hline 4 & & & & $\ldots$ & 0.988 & 0.989 & 0.167 & 0.177 & 0.173 & 0.183 \\
\hline 5 & & & & & $\ldots \ldots$ & 0.996 & 0.164 & 0.140 & 0.152 & 0.178 \\
\hline 6 & & & & & & $\cdots$ & 0.178 & 0.131 & 0.153 & 0.187 \\
\hline 7 & & & & & & & $\cdots$ & 0.937 & 0.986 & 1.000 \\
\hline 8 & & & & & & & & $\cdots \cdots$ & 0.959 & 0.954 \\
\hline 9 & & & & & & & & & $\cdots$ & 0.987 \\
\hline 10 & & & & & & & & & & $\cdots$ \\
\hline
\end{tabular}


western North Atlantic populations of $M$. balthica are not conspecific. Often, genetic similarity values greater than 0.9 are associated with conspecifics, and values less than 0.9 occur between subspecies or species (Avise 1975). Skibinski et al. (1980) examined the genetic similarity among the mussels Mytilus edulis, M. galloprovincialis and Modiolus modiolus. Genetic similarity between the Mytilus species was less than 0.9 , between the genera Mytilus and Modiolus less than 0.25. Buroker et al. (1979a, b) found that the genetic similarity among 5 species of Crassostrea was less than 0.8 , that among conspecific populations greater than 0.9 .

Genetic differentiation, determined by electrophoresis of enzymes, between populations only implies genetic isolation; post-settling selection can create the same differences. However, Macoma balthica has a restricted ability to migrate and it is unlikely that gene flow occurs between eastern and western North Atlantic populations. As a true infaunal bivalve, $M$. balthica is highly adapted to, and dependent upon,

Table 4. Macoma balthica. Summary of genetic differences between populations in the eastern and western North Atlantic Ocean inferred by enzyme electrophoresis

\begin{tabular}{|c|c|}
\hline Locus & $\begin{array}{l}\text { Differences between eastern and } \\
\text { western North Atlantic populations }\end{array}$ \\
\hline MDH-1 & $\begin{array}{l}\text { Locus unique to western North Atlantic } \\
\text { populations }\end{array}$ \\
\hline $\mathrm{MDH}-2$ & $\begin{array}{l}\text { Alleles unique to each side of the North } \\
\text { Atlantic }\end{array}$ \\
\hline PGI & $\begin{array}{l}\text { One unique, rare allele; large differ- } \\
\text { ences in allele frequencies of shared } \\
\text { alleles }\end{array}$ \\
\hline PGM & $\begin{array}{l}\text { Two unique alleles in the western North } \\
\text { Atlantic and } 3 \text { unique alleles in the } \\
\text { eastern North Atlantic }\end{array}$ \\
\hline
\end{tabular}

Table 5. Macoma balthica. Summary of chi-square values and associated P-values for the analyses of heterogeneity of allele frequencies among the populations studied

\begin{tabular}{|lcccc|}
\hline Locus & Alleles & Chi-square & D.F. & P \\
\hline \multicolumn{5}{c}{ Western North Atlantic Ocean } \\
MDH-1 & 3 & 6.183 & 10 & 0.79964 \\
MDH-2 & 2 & 9.792 & 5 & 0.08136 \\
PGI & 6 & 87.353 & 25 & 0.00000 \\
PGM & 5 & 66.469 & 20 & 0.00000 \\
Totals & \multicolumn{5}{c}{0.00000} \\
& Eastern North Atlantic Ocean \\
PGI & 5 & 42.823 & 12 & 0.00002 \\
PGM & 6 & 36.916 & 15 & 0.00130 \\
Totals & \multicolumn{5}{c}{} \\
\end{tabular}

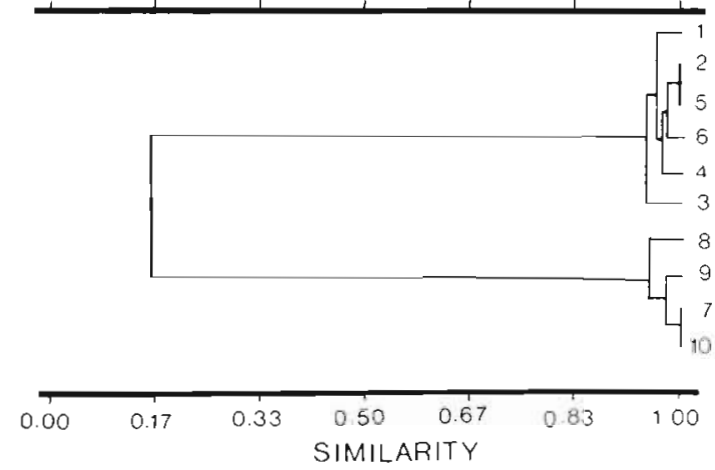

Fig. 1. Macoma balthica. Population phenogram calculated from Nei's unbiased genetic identity (1978), using Biosys-1 (Swofford \& Selander 1981)

its habitat; as an adult it has only a limited ability for survival outside the sediment. $M$. balthica must depend on a passive mode of dispersal utilizing its planktonic larvae. There are 4 primary factors for successful transoceanic transport of teleplanic larvae: direction and speed of available ocean currents, distance between populations, maximum duration of larval development, and larval behavior (Burton \& Feldman 1982, Colebrook 1982, Scheltema 1972a, 1978). The planktonic larval period of $M$. balthica is approximately 2 mo long (Lammens 1967, Ankar 1980, Gilbert 1979). It is generally possible for molluscs to postpone metamorphosis from a planktonic to a benthic state (e.g. Bayne 1965, Seed 1976); there are no indications that $M$. balthica is an exception to this rule. As absolute larval longevity values are unknown, it will be assumed that $M$. balthica can delay metamorphosis for as long as 1 mo, assuming a maximum planktonic larval duration of $90 \mathrm{~d}$. Laboratory experiments with Mytilus edulis (Bayne 1965) indicate that metamorphosis can be delayed up to $40 \mathrm{~d}$ at $10^{\circ} \mathrm{C}$, and $2 \mathrm{~d}$ at $20^{\circ} \mathrm{C}$.

The water currents that would operate as vectors for transoceanic larval transport for Macoma balthica are illustrated in Fig. 2. Using estimates of velocity for transport along these currents (Scheltema 1966), the time required for passive travel from the western to eastern Northern Atlantic ranges from 150 to $300 \mathrm{~d}$. It is apparent that the North Atlantic Ocean currents are not suitable as vectors for direct exchange of planktonic larvae between eastern and western North Atlantic populations.

Another possible mechanism for maintenance of a contiguous range is by utilizing Iceland and Greenland as stepping stones. Berger $(1973,1977)$ and Kraeuter (1974) suggested that Greenland and Iceland operated in the past as stepping stones for the colonization of the North American coast by Littorina littorea. It is unlikely that Greenland and Iceland operate as 
Fig. 2. Distribution of Macoma balthica (stippled areas) and major ocean currents in the North Atlantic Ocean

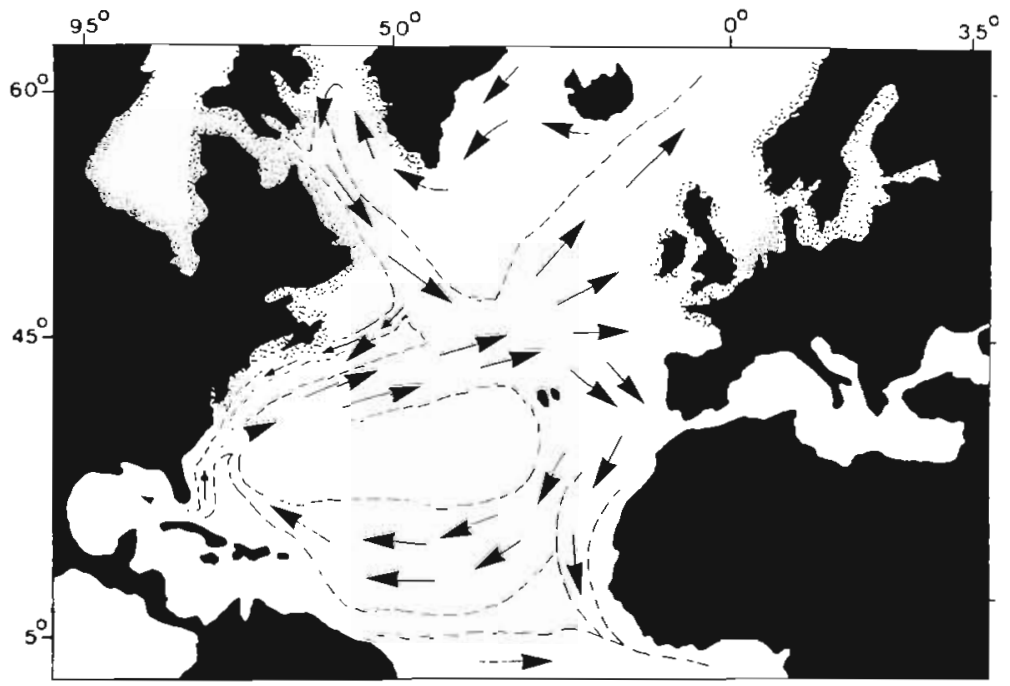

stepping stones for Macoma balthica. This species occurs only on western Greenland (Madsen pers. comm.) and it is not present in coastal or near-shore waters of Iceland (Sparck 1937). A mild modification of this stepping-stone model invoking continental drift may be the most likely model for explaining the establishment of $M$. balthica in its North Atlantic range.

A few sporadic fossil records of Macoma balthica exist for as far back as 60 million yr (Moore 1969). Perhaps $M$. balthica established its amphi-Atlantic distribution during post-genesis of the Atlantic basin, and as the Atlantic broadened by continental drift (Kennett 1982. Hallam 1983), transoceanic exchange of larvae was continually reduced. With this hypothesis, also used to describe the distribution of a number of other species (Sterrer 1973, Vermeij 1978), the tectonic plates can be regarded as slow-moving biotope carrying rafts (Pielou 1979). Therefore, for a considerable length of time, while $M$. balthica was passively extending its range, it was continually inhabiting the same environmental regions and filling the same niches. This transition to allopatry would not involve the invasion of a 'new' habitat; it also would not require any change or adaptive radiation (Schvarts 1977, Stanley 1977). Though $M$. balthica may have once existed as a conspecific population throughout the North Atlantic, possibly as a result of the phenomenon of plate tectonics, it now exists as 2 allopatric populations which are slowly diverging according to the potential of each.

\section{CONCLUSION}

The evidence presented here suggests that Macoma balthica in eastern and western North Atlantic waters should be considered as separate and sibling species.
They are morphologically similar, but geographically isolated and genetically distinct (Mayr 1970). It is recommended that future research in this direction be applied towards interbreeding eastern and western North Atlantic populations, determining the extent of the presence of $M$. balthica on Greenland and the Faeroe Islands, and extensive genetic analysis of both populations, with emphasis on the northern distributional reaches. Also, investigations concerning $M$. balthica should be conducted with caution, when utilizing the world-wide literature concerning this bivalve.

Acknowledgements. Dr. Richard K. Koehn generously provided laboratory space, equipment, and advice concerning electrophoretic techniques. Dr. Jan J. Beukema made available laboratory space and equipment at the Netherlands Institute for Sea Research, for studying European specimens; he was a gracious and generous host. Dr. Robert J. Diaz carefully reviewed the manuscript and provided constructive criticism. Some financial support was provided from The Lerner Gray Fund for Marine Research, a Sigma Xi Minor Research Grant, and a Minor Research Grant from The College of William and Mary.

\section{LITERATURE CITED}

Abbott, R. T (1974). American seashells. Van Nostrand Reinhold, New York

Ankar, S. (1977). The soft bottom ecosystem of the northern Baltic proper with special reference to the macrofauna. Contrib. Aslo Lab., Univ. of Stockholm, Sweden. No. 19: $1-62$

Ankar, S. (1980). Growth and production of Macoma balthica in a northern Baltic soft bottom. Ophelia 1 (Suppl.): $31-48$

Avise, J. C. (1975). Systemic value of electrophoretic data. Syst. Zool. 23: 465-481

Ayala, F. J. (1975). Genetic diferentation during speciation. Evol. Biol. 8: 1-78

Bayne, B. L. (1965). Growth and delay of metamorphosis of the larvae of Mytilus edulis (L.). Ophelia 2: 1-47 
Berger, E. (1973). Gene-enzyme variation in three sympatric species of Littorina. Biol. Bull. mar. biol. hab., woods Hole 145: 83-90

Berger, E. M. (1977). Gene-enzyme variation in three sympatric species of Littorina littorea. II. The Roscoff population. with a note on the origin of North American L. Littorea. Biol. Bull. mar. biol, Lab., Woods Hole 153: 255-264

Beukema, J. J., De Bruin, W. and Jansen, J. J. M. (1978) Biomass and species richness of the macrobenthic animals living on the tidal flats of the Dutch Wadden Sea, long term changes during a period with mild winters. Neth. J. Sea Res. 12: 58-72

Brewer, G. J. (1970). An introduction to isozyme techniques Academic Press, New York

Buroker, N. E., Hershberger, W. K., Chew, K. K. (1979a) Population genetics of the family Ostreidae. I. Intraspecific studies of Crassostrea gigas and Saccostrea commercialis. Mar. Biol, 54: 157-169

Buroker, N. E., Hershberger, W. K., Chew, K. K. (1979b). Population genetics of the family Ostreidae. II. Interspecific studies of the genera Crassostrea and Saccostrea. Mar. Biol. 54: 171-184

Burton, R. S. (1983). Protein polymorphisms and genetic diferentation of marine invertebrate populations. Mar. Biol. Letters 4: 193-206

Burton, R. S., Feldman, M. W. (1982). Population genetics of coastal and estuarine invertebrates: does larval behavior influence population structure? In: Kennedy, V. S. (ed.) Estuarine comparisons. Academic Press, New York, p. 537-552

Castagna, M., Chanley, P. (1973). Salinity tolerance of some marine bivalves from inshore and estuarine environments in Virginia waters on the western mid-Atlantic coast. Malacologia 12: 47-96

Chambers, M. R. Milne, H. (1975). The production of Macoma balthica in the Ythan estuary, Scotland, U. K. Estuar. coast. mar. Sci. 3: 443-455

Colebrook, J. M. (1982). Continuous plankton records: seasonal variations in the distribution and abundance of plankton in the North Atlantic Ocean and North Sea. J. Plankton Res. 4: 435-462

Elliot, M. (1979). Studies on the production ecology of several mollusc species in the estuarine Firth of Forth. Ph. D thesis, University of Sterling, U. K.

Fujio, Y., Yamanaka, R., Smith, P. J. (1984). Genetic variation in marine molluscs. Bull. Jap. Soc. scient. Fish. 49: $1809-1817$

Gilbert, M. A. (1979). Aspects of the reproductive cycle in Macoma balthica (Bivalvia), Nautilus 92: 21-24

Gilman, J. P. (1977). Variation in life history parameters for Macoma balthica, patterns and processes. Am. Zool. 17 : 906

Green, R. H. (1973). Growth and mortality in an Arctic intertidal population of Macoma balthica (Pelecypoda, Tellinidae). J. Fish. Res. Bd Can. 30: 1345-1348

Green, R. H., Singh, S. M., Hicks, B., McCuaig, J. M. (1983). An Arctic intertidal population of Macoma balthica (Mollusca, Pelecypoda): genetic and phenotypic components of population structure. Can. J. Fish. aquat. Sci. 40: 1360-1371

Gooch, J. L. (1975). Mechanism of evolution and population genetics. In: Kinne, O. (ed.) Marine ecology, Vol. II, Physiological mechanisms. Wiley-Interscience, London, $p$. 349-409

Hallam, A. (1983). Early and mid-Jurassic molluscan biogeography and the establishment of the central Atlan- tic seaway. Palaeogeogr. Palaeoclimatol. Palaeoecol. 43: 181-193

Kennett, J. P. (1982). Marine geology. Prentice-Hall, Inc., New Jersey

Koehn, R. K. (1983). Biochemical genetics and adaptation in mollusks. In: Hochachka, P. W. (ed.) Mollusca, Vol. 2. Academic Press, New York, p. 305-331

Koehn, R. K., Mitton, J. B. (1972). Population genetics of marine pelecypods: I. Ecological heterogeneity and evolutionary strategy at an enzyme locus. Am. Nat. 106: $47-56$

Koehn, R. K., Turano, F. J., Mitton, J. B. (1973). Population genetics of marine pelecypods. II. Genetic differences in microhabitats of Modiolus dimissus. Evolution 27 : 100-105

Kraeuter, J. N. (1974). Offshore currents, larval transport and establishment of southern populations of Littorina littorea along the U. S. Atlantic coast. Thalassia jugosl. 10: $159-170$

Lammens, J. J. (1967). Growth and reproduction in a tidal flat population of Macoma balthica. Neth. J. Sea Res. 3: 315-382

Levinton, J. S. (1973). Genetic variations in a gradient of environmental variability: marine Bivalvia. Science, N. Y. 180: $75-76$

Lubinsky, I. (1980). Marine bivalve molluscs of the Canadian central and eastern Arctic: faunal composition and zoogeography. Can. Bull. Fish. Aquat. Sci. 207: 1-111

Markert, C. L. (1975). Isozymes. II. Physiological function. Academic Press, New York

Mayr, E. (1970). Population, species, and evolution. The Belknap Press, Massachusetts

McErlean, A. J. (1967). Characteristics of Macoma balthica populations in the middle Patuxent estuary. Chesapeake Sci. 5: 200-208

McLusky, D. S., Allen, D. G. (1976). Aspects of the biology of Macoma balthica from the estuarine Firth of Forth. J. mollusc. Stud. 42: 31-45

Meehan, B. W. (1984). A morphologic and genetic comparison of Macoma balthica from the eastern and western North Atlantic. Doctoral dissertation. College of William and Mary, School of Marine Science

Mitton, J. B., Koehn, R. K., Prout, T. (1973). Population genetics of marine pelecypods: III. Epistasis between functionally related isoenzymes of Mytilus edulis. Genetics 73: $487-496$

Moore, R. C. (ed.) (1969). Treatise on invertebrate paleontology. Geol. Soc. Am., University of Kansas Press, Kansas

Nevo, E. (1978). Genetic variation in natural populations: pattems and theory. Theor. Populat. Biol. 13: 121-177

Pielou, E. C. (1979). Biogeography. John Wiley and Sons, New York

Reid, R. G. B., Dunnil, R. M. (1969). Specific and individual differences in the esterases of members of the genus Macoma (Mollusca: Bivalvia). Comp. Biochem. Phys. 29: $601-610$

Scheltema, R. S. (1966). Evidence of trans-Atlantic transport of the gastropod larvae belonging to the genus Cymatium. Deep Sea Res. 13: 83-95

Scheltema, R. S. (1972a). Eastward and westward dispersal across the tropical Atlantic ocean of larvae belonging to the genus Bursa (Prosobranchia, Mesogastropoda, Bursidae). Int. Revue ges. Hydrobiol. 57: 863-873

Scheltema, R. S. (1972b). Dispersal of larvae as a means of genetic exchange between widely separated populations of shoal-water benthic invertebrate species. In: Battaglia, 
B. (ed.) Proceedings of the $5^{\text {th }}$ European Marine Biology Symposium. Piccin, Padua, p. 1-48

Scheltema, R. S. (1978). On the relationship between dispersal of pelagic larvae and the evolution of marine prosobranch gastropods. In: Battaglia, B., Beardmore, J. A. (ed.) Marine organisms. Plenum Press, New York, p. 303-322

Schvarts, S. S. (1977). The evolutionary ecology of animals. Transl. by A. E. Gill. Consultants Burea, New York

Seed, R. (1976). Ecology. In: Bayne, B. L. (ed.) Marine mussels: their ecology and physiology. Cambridge University Press, Cambridge, Massachusetts, p. 13-65

Selander, R. K., Hunt, W. G., Yang, S. Y. (1969). Protein polymorphism and genetic heterozygosity in two European subspecies of the house mouse. Evolution 23: $379-390$

Shaw, C. R., Prassad, R. (1969). Starch gel electrophoresis of enzymes - a compilation of recipes. Biochem. Genet. 4: 297-320

Singh, S. M., Zouros, E. (1978). Genetic variation associated with growth rate in the American oyster Crassostrea virginica. Evolution 32: 342-353
Skibinski, D. O. F., Cross, T. F., Ahmad, M. (1980). Electrophoretic investigation of systematic relationships in the marine mussels Modiolus modiolus, Mytilus edulis and Mytilus galloprovinciais (Mytilidae: Mullusca). Biol. J. Linn. Soc. 13: 65-78

Sparck, R. (1937). The benthonic animal communities of the coastal water. Zool. Iceland, part 6: 1-45

Stanley, S. M. (1977). Macroevolution, patterns and process. W. H. Freeman and Co., California

Sterrer, W. (1973). Plate tectonics as a mechanism for dispersal and speciation of interstitial sand fauna. Neth. J. Sea Res. 7: 200-222

Swofford, D. L., Selander, R. B. (1981). Biosys-1: a Fortran program for the comprehensive analysis of electrophoretic data in population genetics and systemics. J. Hered. 72 : 281-283

Theisen, B. F. (1978). Allozyme clines and evidence of strong selection in three loci in Mytilus edulis (Bivalvia) from Danish waters. Ophelia 17: 135-142

Vermeij, G. J. (1978). Biogeography and adaptation, patterns of marine life. Harvard University Press, Massachusetts

This paper was submitted to the editor; it was accepted for printing on November 30,1984 


\section{Erratum}

Re: Meehan, Mar. Ecol. Prog. Ser. 22: 69-76, 1985

- The population numbers in Table 3 and Fig. 1 were incorrect: in both cases, the populations $7,8,9$ and 10 should be changed to $9,10,11$ and 12 